\title{
Contribution of Corporate Governance on Performance of Listed Companies in Kenya
}

\author{
R. M. Isaac
}

\section{ABSTRACT}

Leadership is a process of social influence in which one person can enlist the aid and support of others in the accomplishment of a common task. Corporate governance has dominated leadership policy agenda in developed market economies for more than a decade and African continent is gradually adopting it on their policy agenda on leadership and governance of their organisations. The Nairobi Securities Exchange (formerly Nairobi Stock Exchange) (NSE) is the principal stock exchange of Kenya. This study was to establish the contribution of Corporate Governance on leadership performance of Listed Companies in Kenya. The target population consisted of the 62 listed companies that had been listed at the NSE in 2015. The study used primary data which was collected using questionnaires. Data was analysed and presented using the Statistical Package for Social Sciences (SPSS). Descriptive and inferential statistics were used to present the results of this study. The study found that good corporate governance is a major ingredient to leadership performance and there must be deliberate effort by company leadership to create systems that ensure there is effective corporate governance. The study recommends that board of directors should actively promote long term performance, take control of the company business and significantly promote growth in financial performance, market performance, shareholder return, share value and customer satisfaction. The study encourages company leaders to draw strong strategies to counter any political interferences, ethnicity and nepotism which are the major cancerous effect to leadership styles and structures, leadership composition, leadership independency, stakeholders' ownership and ownership concentration which are significant factors to performance.

Keywords: Boards of Directors, Corporate Governance, Leadership performance, Nairobi Securities Exchange.

\section{INTRODUCTION}

Ibrahim Index of African Governance (2007) defines governance as the provision of the political, social, and economic goods that a citizen has the right to expect from his or her state, and that a state has the responsibility to deliver to its citizens. According to Mensah (2012), governance is referred to mean all processes of governing, whether undertaken by a government, market, or network, whether over a family, tribe, formal or informal organization or territory and whether through laws, norms, power, or language. He further stated that it relates to the processes of interaction and decision-making among the actors involved in a collective problem that led to the creation, reinforcement, or reproduction of social norms and institutions. Governance is the dynamic interaction between people, structures, processes, and traditions that support the exercise of legitimate authority in provision of sound leadership, direction, oversight, and control of an organization in order to ensure that there is proper accounting for the conduct of its affairs, the use of its resources, and the results of its activities (Coward, 2010).

Corporate Governance is defined as the system by which corporations are directed, controlled, and held to account (Solomon, 2013). He further noted it's the manner in which
Submitted : December 14, 2021

Published : January 22, 2022

ISSN: $2507-1076$

DOI: $10.24018 /$ ejbmr.2022.7.1.1202

R. M. Isaac

The East African University, School of Business, Kenya.

(e-mail: rimwangangi@gmail.com) the power of or over a corporation is exercised in the stewardship of its total portfolio of assets and resources so as to increase and sustain shareholder value while satisfying the needs and interests of all stakeholders. Wellage (2012) study quoted the Australian Stock Exchange (ASX) Corporate Governance Council (2010) which defines corporate governance as the framework of rules, relationships, systems, and processes by which corporations are directed and controlled. He further noted that the UK Corporate Governance Code (2010) which states that levels of remuneration should be sufficient to attract, retain and motivate directors of the quality required to run the company successfully but a company should avoid paying more than necessary for this purpose.

A study by Miring'u and Muoria (2011) indicated that as early as 1970s, many governments in Africa had recognized the fact that public companies were performing poorly. They noted that the poor state companies' performance was associated with labour rigidities in the market increased fiscal and foreign debt and inflation problems. Further they noted that the companies provided poor and unreliable services, failed to meet demand, and were lagging behind in technology areas. They concluded that mismanagement, bureaucracy, wastage, pilferage incompetence and irresponsibility by directors and employees are the main 
problems that have made state companies to fail to achieve their objectives. Although developing countries are increasingly embracing the concept of corporate governance knowing it leads to sustainable economic growth, collapse of their listed companies is on the rise. Some companies including state corporations have folded up partly as a result of corporate governance problems as observed in South Africa by Gossel and Biekpe (2014).

The Nairobi Securities Exchange (formerly Nairobi Stock Exchange) is the principal stock exchange of Kenya. It began in 1954 as an overseas stock exchange while Kenya was still a British colony with permission of the London Stock Exchange. The NSE is a member of the African Stock Exchanges Association. It is Africa's fourth largest securities exchange in terms of trading volumes, and fifth in terms of market capitalization as a percentage of Gross Domestic Product. The Exchange works in cooperation with the Uganda Securities Exchange and the Dar es Salaam Stock Exchange, including the cross listing of various equities. Trading is done through the Electronic Trading System which was commissioned in 2006. A Wide Area Network platform was implemented in 2007 and this eradicated the need for brokers to send their staff (dealers) to the trading floor to conduct business. Trading is now mainly conducted from the brokers' offices through the WAN. In order to provide investors with a comprehensive measure of the performance of the stock market, the Nairobi Stock Exchange introduced the NSE All-Share Index in 2008. In 2009 the Exchange launched its Complaints Handling Unit in a bid to make it easier for investors and the general public to forward any queries and access prompt feedback (NSE, 2015).

Solomon (2013) noted that the World Bank and the International Monetary Fund (IMF) had begun imposing tough conditions that touched on governance and better economic management to NSE. Although the policies achieved some benefits, the country is still caught up in macro-economic instability as evidenced by high inflation rates, account deficits and policy uncertainties (Njanja, Ogutu \& Pellisier, 2012). Kenya Airways Ltd in Kenya has been noted to win several good corporate governance awards for the last five years but the company continued to perform poorly over the period. The company had its Earnings Per Share operating between (-ve )13.35 and (-ve)2.25 down from 10.45 in 2006 and operating on downward share price trend of Kes. 5.00 down from Kes. 34.50 in 2011 and making losses year after year (NSE, 2015). Kenya listed companies' poor performance state was also witnessed in Euro Bank, Uchumi Supermarkets, Unga Group, National Bank of Kenya, CMC Motors, Eveready (K) Ltd and East Africa Industries among many others (Madiavale, 2011).

Mulili (2011) noted that politically, Kenya was governed through a one-party autocratic rule from the time of independence in 1963 to January 2003 when multiparty politics were reintroduced, and a new government elected to office. Mulili (2011) further noted that the affirmation of the Kenya Constitution 2010 changed the way politics was played and brought in a new dimension to the way corporate governance was to be exercised on Kenyan companies. Nafukho \& Muyia (2014) notes that socially, Kenya is made of 42 tribes and the tribal differences are highly pronounced in all sectors of the society. He further said that a major social trend in the country has been experienced on corporate governance to Kenyan companies, partly owing to the demands of an increasingly sophisticated economy. Secondly, freedom of speech, he said, brought about by the Kenya Constitution 2010 is rampant in the country, and the citizens are free to question anything that does not seem to make sense to them on the way corporate governance is being dispensed on running of the Kenyan organisations. He concluded that there are increased efforts to reduce the prevalence of corruption and pressure groups tend to advocate for all forms of social change and as a result of these changes, there is a great push for improved corporate governance on all sectors.

\section{Statement Of The Problem}

A good corporate governance mechanism is assessable from; political stability, accountability, government effectiveness, rule of law, control of corruption and quality of regulation which can only be achieved through sound and effective leadership (Kaufmann, Kraay \& Mastruzzi, 2012). Chung, Kim, Park and Sung (2013) examined the relation between transparency related governance attributes and liquidity in the U.S. stock market and found out that corporate governance has a strong positive influence on organisational performance. According to Yang (2012), companies with good corporate governance systems in place have more efficient operations that lead to high company performance.

A study by McConvill (2012) noted numerous cases world over of companies' leadership such as Enron, Worldcom, Marconi and Royal Ahold where this relationship contradicted. Also, a study by Iraya, Mwangi and Muchoki (2015) noted cases of non-performing listed companies in Kenya that have attracted debates in their form of leadership and shaken both local and foreign investor confidence. Companies such as Kenya Airways Ltd, Eveready (EA) Ltd, Uchumi Supermarkets, Unga Group Ltd, National Bank of Kenya and CMC Holdings Ltd have in the past won several good corporate governance awards but have poor leadership performance indicators (NSE, 2015). Further, a study by Madiavale (2011) noted that although in Kenya listed companies have adopted corporate governance leadership practices, cases of organisations scandals that lead to poor company leadership performance are rampant.

There were literatures on corporate governance on how it contributes to company leadership performance, however, some listed companies in Kenya despite embracing corporate governance have dismal overall leadership performance (NSE, 2015). The problem was that some listed companies in Kenya had poor leadership performance. Even with all the empirical evidence on positive relationships between corporate governance and company leadership performance and the government laid up Corporate Governance structures, some Kenya listed companies continue to operate on losses over the last five years. This affected shareholders, employees, customers, creditors, managers, suppliers, the wider community, and the country's economy. The implication was that stakeholder suffered and the investors, prospective and actual shareholders, accordingly, lose confidence in the market and withdraw and the country's economy do not grow (Hudson, 2013). Corporate governance 
although a common phenomenon in Kenya, the level of preparedness of the listed companies' leadership to face up with the identified challenges and potential complexities to ensure that they are managed to the desired performance is a major concern. This study is a step toward understanding the contribution of leadership composition on leadership performance of listed companies in Kenya as the survival of any organisation is dependent upon how it deals with sources of uncertainty or dependency.

\section{LITERATURE REVIEW}

\section{A. Corporate Governance Theories}

According to Lashgari (2014), corporate governance is concerned with managing the relationship among various organisation stakeholders. Much of the literature on corporate governance implicitly assumes that only listed organisations are the subject of analysis (Agyemang \& Aboagye, 2013). They noted that various theories and philosophies have provided the foundation for the development of alternative forms of corporate governance systems around the world as corporate governance is concerned with managing the relationship among various corporate stakeholders. Studies indicate fundamental theories underlining corporate governance range from the agency theory and expanded into stewardship theory, stakeholder theory, resource dependency theory, transaction cost theory, political theory and ethics related theories such as business ethics theory, virtue ethics theory, feminists' ethics theory, discourse theory and postmodernism ethics theory.

\section{B. Agency Theory}

Agency theory having its roots in economic theory was exposited by Alchian \& Demsetz (1972) and further developed by Jensen \& Meckling (1976) and is defined as the relationship between the principals, such as shareholders, and agents such as the company executives and managers. In this theory, shareholders who are the owners or principals of the company, hires the agents to perform work. According to Clarke \& Branson (2012) principals delegate the running of business to the directors or managers, who are the shareholder's agents.

Mallin (2015) argued that agency theory identifies the relationship where one party, the principle, delegates work to another, the agent. He states that the principal agent model regards the central problem of corporate governance as self interested managerial behaviour in a universal principal agent relationship. Further he notes that this separation is however, linked and governed through proper agency relationship at various levels, among others between shareholders and boards of directors, between boards and senior management, between senior and subordinate levels of management. He concludes in such a principal agent relationship, there is always inherent potential for conflicts within a firm because the economic incentives faced by the agents are often different from those faced by the principals. He quoted International Swaps and Derivatives Association (ISDA, 2002) that all companies are exposed to agency problems and to some extent develop action plans to deal with them.

According to Mishra et al. (2014), agency theory provides a framework that links corporate governance with firms' performance. Within agency theory framework, companies are defined as nexus of contracts under which one party (the principal) engages with another party (the agent) to perform some service on their behalf (Subramaniam, Stewart \& Shulman, 2013). They further stated that on the one hand, the agent is generally assumed to act based on his/her self interest and the principal monitors agent's behaviour through adopting governance mechanisms. Studies indicate that since corporate governance mechanisms provide additional checks on managerial behaviour, governance mechanisms not only reduce the possibility that top managers will enhance their interests by using information asymmetries but also force managers to behave in such a way that maximize shareholders' value (Liu \& Subramaniam, 2013). Liu et al. (2013) stated that agency problems arise when the agent does not share the principal's objectives and further quotes Berle $\&$ Means (2011) that the separation of ownership and control increases the power of professional managers and leaves them free to pursue their own aims and serve their own interests at the expense of shareholders.

\section{Stewardship Theory}

Stewardship theory and agency theory have both focused on the leadership philosophies adopted by the owners of an organization. According to Block \& Piersanti (2013) stewardship theory assumes that some features of the internal governance structure could affect the ability of the steward to perform his/her duties and also can be counterproductive due to affecting his/her incentives and so he concluded the governance structure should give the CEO complete authority over the firm's activities (management and control decisions) in order to maximise the shareholders' value. Unlike agency theory, stewardship theory stresses not on the perspective of individualism, but rather on the role of top management being as stewards, integrating their goals as part of the organization (Aras et al., 2013). The stewardship perspective suggests that stewards are satisfied and motivated when organizational success is attained. Aras et al. (2013) insists that agency theory looks at an employee or people as an economic being, which suppresses an individual's own aspirations, while stewardship theory recognizes the importance of structures that empower the steward and offers maximum autonomy built on trust.

Aras et al. (2013) also stated that in contrast to the agency theory, stewardship theory argues that there are non-financial or intangible motivations that could alleviate opportunistic managerial behaviour. They explained that the CEO under this perspective is assumed to inherently have the motivation to maximise the firm's value, as the leader or the steward of the principals' assets. Stewardship theory has its roots from psychology and sociology and Aras et al. (2013) states that steward protects and maximises shareholders wealth through firm performance, because by so doing, the steward's utility functions are maximised. They also observed that the steward theory supports the CEO/chairman duality of which the firm enjoys benefits from this unity of command and control, and thus shareholders enjoy superior returns, better than what they would get with the separation of these positions. In this perspective, stewards are company executives and managers working for the shareholders, protects and make profits for the shareholders. 
Albrecht, Albrecht \& Albrecht (2013) study observed that the CEO's behaviour is believed to be collective rather than individualistic under this perspective and stewardship theory emphasises the importance of organisational structures that play authorising, facilitating, and empowering roles rather than controlling and monitoring ones. Stewardship theorists argue that this way of explaining the relationship between shareholders and managers leads to additional benefits beside the benefits that the firm obtains from the directors' help in terms of management decisions as experts in business, which are likely to contribute to increasing the shareholders' wealth, other benefits come through reducing the monitoring costs that the shareholders usually incur to supervise the managerial activities. Consequently, from this perspective the board of directors is considered as an instrument which assists the CEO, rather than as a monitoring mechanism.

\section{Transactional Cost Theory}

Transaction cost theory was first initiated by Cyert \& March (1963) and later theoretical described and exposed by Williamson (1996). They stated that transaction cost theory was an interdisciplinary alliance of law, economics, and organizations. Further, they argued that the theory attempts to view the firm as an organization comprising people with different views and objectives. The underlying assumption of transaction theory, they concluded, was that firms had become so large that they in effect substitute for the market in determining the allocation of resources; in other words, the organization and structure of a firm could determine price and production. They also noted that the unit of analysis in transaction cost theory was the transaction and therefore the combination of people with transaction suggests that transaction cost theory managers were opportunists and arranged firms' transactions to their interests.

Williamson (1996) states that the transaction costs theory deals with the ideal transaction mode of corporations arguing that organisations choose this best possible mode between the extreme of market exchange and hierarchy, which leads to the lowest possible transaction and production costs. According to La-Porta, Lopez-de-Silanes, Shleifer \& Vishny (2002), transaction costs theory has been primarily introduced to developed economies where there are strong regulatory systems, social norms, and mutual trust, however, emerging economies due to uncertainty and lower regulatory system increases transaction costs. Moreover, transaction costs theorist explains that a firm's environment is the main determinant of transaction costs (Williamson, 1996). Hoskisson, Johnson, Tihany \& White (2005) explained that where market transaction costs are high the hierarchical governance model will enhance efficiency.

\section{E. Stakeholders Theory}

The stakeholders' theory was embedded in the management discipline in 1970 and gradually developed by Freeman incorporating corporate accountability to a broad range of stakeholders. Freeman (2010) argued that stakeholder theory derived from a combination of the sociological and organizational disciplines. The researchers felt that the agency and resource dependency theories cannot suffice because of their emphasis on organisation as fragmented and closed social units independent of external forces.
To provide voice and ownership-like incentives to critical stakeholders, Porter (1992) recommended the stakeholders theory to US policy makers so as to encourage long-term employee ownership and encourage board representation by significant customers, suppliers, financial advisers, employees, and community representatives. He also recommended that corporations seek long-term owners and give them a direct voice in governance (i.e., relationship investors) and to nominate significant owners, customers, suppliers, employees, and community representatives to the board of directors.

The only meaningful way to study an organisation is to regard it as a system. According to Mitchell, VanBuren, Greenwood, \& Freeman (2015) organisation is a system of stakeholders operating within the larger system of the host society that provides the necessary legal and market infrastructure for the firm's activities. He further states that the purpose of the organisation is to create wealth or value for its stakeholders by converting their stakes into goods and services. The stakeholder theory holds that corporations are social entities that affect the welfare of many stakeholders where stakeholders are groups or individuals that interact with a firm and that affect or are affected by the achievement of the firm's objectives (Donaldson \& Preston, 1995; Freeman, 2010; Reed, 2002). They further stated that the key to achieving this is to enhance the voice of and provide ownership like incentives to those participants in the firm who contribute or control critical, specialized inputs (organisation specific human capital) and to align the interests of these critical stakeholders with the interests of independent, passive shareholders. According to Mulili (2011), successful organisations are judged by their ability to add value for all their stakeholders. Some scholars, such as Starik \& Rands (1995), consider the natural environment as a key stakeholder. Further, the ability to successfully interact with the external environment, in line with the resource dependency theory, can be a source of competitive advantage for a firm (Okpara, 2011).

Mackenzie (2014) noted a corporation adopts a reactive approach when it does not integrate stakeholders into its corporate decision-making processes, and this results in a misalignment of organisational goals and stakeholder demands. Some authors attribute scandals such as those of Enron and WorldCom to the failure to consider stakeholder concerns in decision making (Currall, Frauenheim, Perry \& Hunter, 2014; Clarke \& Branson, 2012; Watkins, 2003; Zandstra, 2012). A proactive approach is used by corporations that integrate stakeholder concerns into their decision-making processes; such corporations also establish necessary governance structures (Schouten, Wade \& Wit, 2006).

\section{F. Resource Dependency Theory}

Whilst the stakeholder theory focuses on relationships with many groups for individual benefits, resource dependency theory concentrates on the role of board directors in providing access to resources needed by the firm. Hillman, Canella \& Paetzold (2000) contend that resource dependency theory focuses on the role that directors play in providing or securing essential resources to an organization through their linkages to the external environment. Indeed, Johnson, Daily \& 
Ellstrand (1996) concurs that resource dependency theorists provide focus on the appointment of representatives of independent organizations as a means for gaining access in resources critical to firm success. According to Hillman et al. (2000) directors bring resources to the firm, such as funds, information, skills, access to key constituents such as suppliers, buyers, public policy makers, social groups as well as legitimacy.

Johnson, et al. (1996) notes the theory concentrates on the role of directors in securing access to resources critical to the success of the firm. Further, the theory argues that some firms prefer to appoint directors from independent organisations that have the resources needed by the firms. Abdullah, Yasser, \& Rahman (2013) study classified directors into four categories, namely insiders, business experts, support specialists and community influentials. Darley, Luethge \& Blankson (2013) and Turnbull (2002), studies noted a firm relying on the resource dependency theory would appoint directors from the business experts (e.g., current or former chief executives of other profit-making firms), support specialists (e.g., lawyers, bankers, insurance company representative, public relations experts) and community influentials (e.g., political leaders, members of the clergy, leaders of community service organisations, university faculty). Further, the support specialists would, for instance, be able to provide access to essential services like credit facilities and legal advice at reasonable costs.

\section{G. Company Performance}

Leadership is the process of motivating other people to act in particular ways in order to achieve specific goals (Hannagan, 2008). Hannagan (2008) further argued that in all organisations, leadership is required in order for its objectives to be achieved and good leadership can result in success while poor leadership can lead to failure. There are several approaches to understand leadership, ranging from traditional, behavioural, contingency, and modern approaches. In whichever approach leadership is applied some leaders' behaviour will be noticed ranging from directive, supportive, participative and achievement oriented leadership. The pressures to adopt a particular leadership style are seen through the effects of organisation culture and peer expectations. Leaders will need to lay strategy, plan on the allocation of the available resources and apply corporate governance principles to achieve the level of company performance desired.

According to Mishra \& Mohanty (2014) leadership performance is the most important criterion in evaluating organizations, their actions and environments. They noted that organizational performance encompasses the following specific areas of firm outcomes: financial performance (profits, return on assets, return on investment, etc.); market performance (sales, market share, etc.); shareholder return (total shareholder return, economic value added, etc.) and customer satisfaction (customer retention, loyalty, products and service attributes, image and reputation, etc). Dutta $\&$ Fan (2014) stated that the nature of company performance measures can also be firm specific, depending on internal policies as cash flows, accounting numbers and stock prices produce different incentives for managers. They concluded that measuring performance requires weighing the relevance of the company performance to focal stakeholders.

At the most basic level, small and large firms are likely to perform in quite different manners although linked by competition; these firms have very different resources and strategies (Malina \& Euske, 2013). In a cross-country survey by Liston, Chong \& Bayram (2014) found that small Finnish and UK companies focused on profitability, product margins, customer satisfaction and liquidity. They further stated that within the strategy, economics and finance literatures market value-based measures are the preferred instrument for characterizing organizational performance. The greatest strength of these measures is that they are forward looking, in theory representing the discounted present value of future cash flows (Fisher, Strickland, \& Knobe, 2012). They also incorporate intangible assets more effectively than accounting data, something of clear relevance to those interested in resource based and knowledge-based views of the firm (Lev, Demerjian, and McVay, 2012).

According to Levenson \& Stede (2011), the relationship between measures and performance is also influenced by which measures the firm uses internally and how these are embedded into incentive and control systems within the firm, e.g., the firm's own key performance indicators. They noted the internal measurement systems used could influence performance at the individual and organizational level. Fisher et al. (2012) noted that within the strategy, economics and finance literatures market value-based measures are the preferred instrument for characterizing organizational performance. They further stated that the greatest strength of these measures is that they are forward looking, in theory representing the discounted present value of future cash flows. They also incorporate intangible assets more effectively than accounting data, something of clear relevance to those interested in resource based and knowledge-based views of the firm (Lev et al., 2012). Levis, et al. (2012), however, noted that the connection between market measures to the actual performance of the firm depends on how much of the rent generated from its activities flows to shareholders and the informational efficiency of the market. He further stated that the usual justification of these measures is that firms are instruments of shareholders. Merchant, Stede, Lin, and Yu (2011) noted that although market value might be generally recognized as the most appropriate measure of overall organizational performance, it is less useful for research focusing on performance where the dimensionality is defined in terms of a product or a strategic business unit. He concluded that an advantage of mixed market/accounting measures is that they are better able to balance risk (largely ignored by accounting measures) against operational performance issues that are sometimes lost in market measures.

Similarly, scholars in marketing, operations and management seek to understand and improve performance, each adopting discipline-specific measures such as customer satisfaction, productivity, and employee satisfaction (Chenhall \& Langfield-Smith, 2011).

\section{H. Conceptual Framework}

According to Marshall and Rossman (2010), a conceptual framework is tool researchers use to guide their inquiry; it is 
a set of ideas used to structure the research. Burns and Burns (2012) define a conceptual framework as an interconnected set of ideas (theories) about how a particular phenomenon functions or is related to its parts. It is a diagrammatic, flow chart or figurative illustration explaining the relationships between factors and variables identified, relevant to the study (Oso \& Onen, 2011; Burns et al., 2012). They stated that the major function of a structural framework is that it enables the study to find links between the existing literature and own research goals. The thesis focused on combined approaches as each individual has different roles which they have to perform, for example, the role of shareholders and the board of directors.

The conceptual framework depicted in Fig. 1 where corporate governance is hypothesised to influence company performance is characterised by leadership Structures, composition, independence, stakeholders' ownership, and ownership concentration which are independent variables and the company performance which is the dependent variable. Accountability, transparency; fairness; insiders, business and support experts, shareholders, board of directors, management directors, firm size, firm value, majority shares, profits, market share, share returns and customer satisfaction are the research dependent variable constructs.

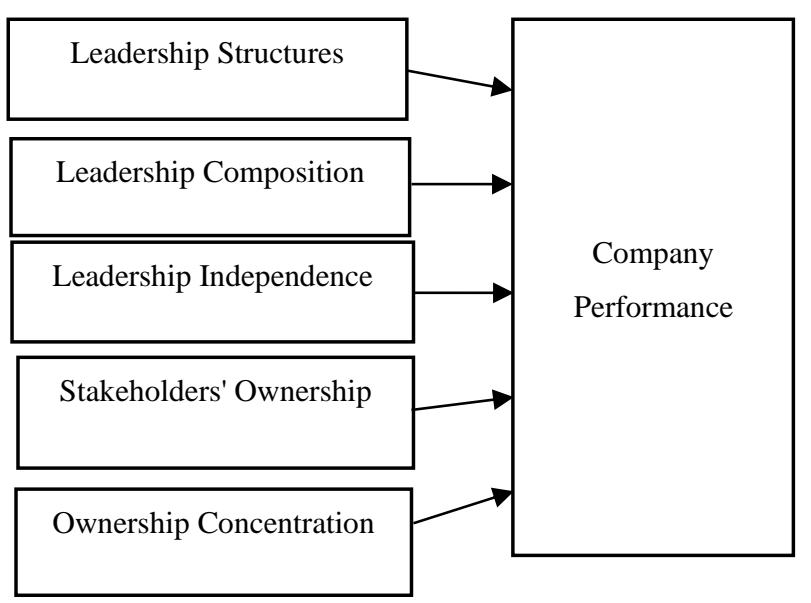

Fig. 1. Conceptual Framework.

\section{Objectives}

The general objective of this study was to ascertain the contribution of corporate governance leadership practices on performance of listed Companies in Kenya. The study pursued the following specific objectives:

1) To establish the contribution of leadership Structure on performance of listed companies in Kenya;

2) To determine the contribution of leadership composition on performance of listed companies in Kenya;

3) To examine the contribution of leadership independence on performance of listed companies in Kenya;

4) To explore the contribution of stakeholders' ownership on performance of listed companies in Kenya;

5) To assess the contribution of ownership concentration on performance of listed companies in Kenya.

This study sought to test the following research hypotheses:

1) Ho1: Leadership Structure has no significant contribution on performance of listed companies in Kenya.

2) Ho2: Leadership composition does not have significant contribution on performance of listed companies in Kenya.

3) Ho3: Leadership independence has no significant contribution on performance of listed companies in Kenya.

4) Ho4: Stakeholders' ownership has no significant contribution on performance of listed companies in Kenya.

5) Hos: Ownership concentration has no significant contribution on performance of listed companies in Kenya.

\section{Methodology}

This study adopted a descriptive research design. The study targeted listed companies' staff in all levels and the target population was the 62 listed companies in Kenya (NSE 2015). The sample for this study consisted of nine (9) listed companies.

Data was collected from a sample size of 237 employee respondents by use of structured questionnaires. Stratified and simple random sampling techniques were used to determine the sample size.

The hypothesis testing was done at $5 \%$ level of significance and SPSS was used for this purpose. A multiple linear regression model was used to test the significance of the influence of the independent variables on the dependent variable. The multiple linear regression model was as laid below:

$$
Y=\alpha+\beta_{1} X_{1}+\beta_{2} X_{2}+\beta_{3} X_{3}+\beta_{4} X_{4+} \beta_{5} X_{5}+\mu
$$

where

$Y=$ Company performance (dependent variable);

$\alpha=$ Constant;

$\beta_{1} \ldots \beta_{5}=$ Coefficients of independent variables;

$\mathrm{X}_{1 \ldots .} \mathrm{X}_{5}=$ Values of the various independent (covariates) variables;

$\mathrm{X}_{1}=$ Leadership Structure;

$\mathrm{X}_{2}=$ Leadership composition;

$\mathrm{X}_{3}=$ Leadership independence;

$\mathrm{X}_{4}=$ Stakeholders' ownership;

$\mathrm{X}_{5}=$ Ownership concentration;

$\mu=$ Error term which is assumed to be normally distributed with mean zero and constant variance.

\section{RESULTS AND DISCUSSION}

A total of two hundred and thirty-seven (237) questionnaires were distributed to the nine companies targeted for the study. From the study, 182 questionnaires were duly filled and returned. However, after cleaning for outliers, the remainder was 175 questionnaires making a response rate of $74 \%$. A simple majority $(66.1 \%)$ of the respondents were male while the rest $(33.9 \%)$ of the respondents were female. Majority $(54.4 \%)$ of the respondents were subordinate, $26.9 \%$ supervisory, $14.3 \%$ middle and top management designates with a paltry $(4.4 \%)$. Majority $(79.5 \%)$ of the respondents had a working 
experience of 6 years and above and only $(20.5 \%)$ had below 6 years of experience.

\section{A. Descriptive Statistical Analysis on Company Performance of Listed Companies}

Table I provides the opinions and responses on the questions which show that a majority of $60.9 \%$ (sum of 39.6 and $21.3 \%$ ) of the respondents agreed that the leadership performance of listed companies is the responsibility of board of directors.

TABLE I: STATISTICAL RESULTS FOR COMPANY PERFORMANCE

\begin{tabular}{cccccc}
\hline Variable indicators & $\begin{array}{c}\text { Strongly } \\
\text { Disagree }\end{array}$ & Disagreeneutral Agree & $\begin{array}{c}\text { Strongly } \\
\text { Agree }\end{array}$ \\
\hline $\begin{array}{c}\text { Our company profits go up every } \\
\text { year. }\end{array}$ & $1.1 \%$ & $11.4 \%$ & $26.3 \%$ & $38.9 \%$ & $22.3 \%$ \\
$\begin{array}{c}\text { Our company market share is } \\
\text { growing yearly. }\end{array}$ & $0.0 \%$ & $10.9 \%$ & $28.0 \%$ & $42.3 \%$ & $18.9 \%$ \\
$\begin{array}{c}\text { Our shareholders and stakeholders } \\
\text { are getting good returns every end } \\
\text { of the year }\end{array}$ & $1.7 \%$ & $8.0 \%$ & $23.4 \%$ & $42.3 \%$ & $24.6 \%$ \\
$\begin{array}{c}\text { Our company share value is } \\
\text { constantly growing }\end{array}$ & $4.6 \%$ & $19.4 \%$ & $21.7 \%$ & $37.7 \%$ & $16.6 \%$ \\
$\begin{array}{c}\text { Our company corporate image is } \\
\text { appealing and promotes the } \\
\text { company performance } \\
\text { Average }\end{array}$ & $2.9 \%$ & $10.3 \%$ & $26.3 \%$ & $36.6 \%$ & $24.0 \%$ \\
\hline
\end{tabular}

Table II presents the weighted means of the dependent variable, company performance of listed companies.

TABle II: Weighted MeAns For COMPANy PERFORMANCE

\begin{tabular}{|c|c|c|c|c|c|}
\hline \multirow[b]{2}{*}{ Financial Performance } & \multicolumn{2}{|c|}{ NMinimum } & \multicolumn{2}{|c|}{$\begin{array}{c}\text { MaximuMean } \\
\mathrm{m}\end{array}$} & \multirow{2}{*}{$\begin{array}{c}\begin{array}{c}\text { Std. } \\
\text { Deviation }\end{array} \\
0.980\end{array}$} \\
\hline & 175 & 1 & 5 & 3.70 & \\
\hline Market share & 175 & 1 & 5 & 3.69 & 0.901 \\
\hline $\begin{array}{l}\text { Shareholders \& } \\
\text { Stakeholders Returns }\end{array}$ & 175 & 1 & 5 & 3.80 & 0.959 \\
\hline Company Share Value & 175 & 1 & 5 & 3.42 & 1.116 \\
\hline Corporate Image & 175 & 1 & 5 & 3.69 & 1.039 \\
\hline
\end{tabular}

\section{B. Regression Analysis}

In this study the researcher performed hierarchical regression analysis to determine the actual order of entry of the variables (both predictor and outcome variables). The general objective of this study was to determine the role of corporate governance on company performance in listed companies in Kenya.

TABLE III: REGRESSION MODEL FITNESS FOR THE INDEPENDENT VARIABLES

\begin{tabular}{ccccc}
\hline Model & $\mathrm{R}$ & $\mathrm{R}^{2}$ & Adj R $^{2}$ & $\begin{array}{c}\text { Std. Error of the } \\
\text { Estimate }\end{array}$ \\
\hline 1 & $0.435^{\mathrm{a}}$ & 0.189 & 0.165 & 3.724 \\
\hline
\end{tabular}

a. Predictors: (Constant), Ownership Concentration, Stakeholders Ownership, Leadership.
Table III shows that there was a $43.5 \%$ positive correlation (R) between the independent variables and the dependent variable, leadership performance of listed companies in Kenya and further indicates that up to $18.9 \%\left(\mathrm{R}^{2}\right)$ of the change in the leadership performance of listed companies in Kenya can be explained by the combined effect of the five independent variables of the study.

\section{ANOVA for Integrated Regression Model}

The results obtained (Table IV) show that the p-values are equal to .000; a demonstration that regression models for the study is statistically significant considering that their $p$-value is less than .05 at the $95 \%$ level of confidence.

TABLE IV: ANOVA ON THE INDEPENDENT VARIABLES

\begin{tabular}{|c|c|c|c|c|c|c|}
\hline \multicolumn{7}{|c|}{ ANOVA $^{a}$} \\
\hline \multicolumn{2}{|c|}{ Model } & $\begin{array}{l}\text { Sum of } \\
\text { Squares }\end{array}$ & $\mathrm{df}$ & Mean Square & F & Sig. \\
\hline \multirow[t]{3}{*}{1} & $\begin{array}{c}\text { Regressi } \\
\text { on }\end{array}$ & 546.852 & 5 & 109.370 & 7.887 & $0.000^{\mathrm{b}}$ \\
\hline & Residual & 2343.696 & 169 & 13.868 & & \\
\hline & Total & 2890.549 & 174 & & & \\
\hline
\end{tabular}

a. Dependent Variable: Leadership Performance.

b. Predictors: (Constant), Ownership Concentration, Stakeholders Ownership, Leadership Composition, Leadership and Structure, Leadership Independence.

Using the summaries contained in Tables $\mathrm{V}$, a linear regression model, combining all the independent variables can be presented in the form:

$$
Y=\alpha+\beta_{1} X_{1}+\beta_{2} X_{2}+\beta_{3} X_{3}+\beta_{4} X_{4+} \beta_{5} X_{5}+\varepsilon
$$

This also confirms that the linear model fits the data quite well. The model estimate for leadership performance is therefore represented as follows as:

$$
Y=0.074 X_{1}+0.214 X_{2}+0.135 X_{3}+0.101 X_{4}+0.254 X_{5}-4.802
$$

where

$\alpha=$ A constant, $=-4.802$;

$\beta_{1}=0.074$

$X_{1}=$ Leadership \& Structures;

$\beta_{2}=0.214$;

$X_{2}=$ Leadership Composition;

$\beta_{3}=0.135$;

$X 3=$ Leadership Independence;

$\beta_{4}=0.101$

$X 4=$ Stakeholders Ownership;

$\beta_{5}=0.254$

$\boldsymbol{X 5}=$ Ownership Concentration;

$\varepsilon=$ Error term

\begin{tabular}{|c|c|c|c|c|c|c|}
\hline & \multirow[t]{2}{*}{ Model } & \multicolumn{2}{|c|}{$\begin{array}{l}\text { Unstandardized } \\
\text { Coefficients }\end{array}$} & \multirow{2}{*}{$\begin{array}{c}\text { Standardized } \\
\text { Coefficients } \\
\text { Beta }\end{array}$} & \multirow[t]{2}{*}{$\mathrm{t}$} & \multirow[t]{2}{*}{ Sig. } \\
\hline & & $\mathrm{B}$ & Std. Error & & & \\
\hline \multirow[t]{6}{*}{1} & (Constant) & -4.802 & 1.714 & & -2.801 & 0.000 \\
\hline & Leadership \& Structure & 0.074 & 0.130 & 0.077 & 0.566 & 0.572 \\
\hline & Leadership Composition & 0.214 & 0.074 & 0.252 & 2.881 & 0.004 \\
\hline & Leadership Independence & 0.135 & 0.158 & 0.136 & 0.832 & 0.396 \\
\hline & Stakeholders Ownership & 0.101 & 0.091 & 0.096 & 1.106 & 0.270 \\
\hline & Ownership Concentration & 0.254 & 0.147 & 0.261 & 1.731 & 0.085 \\
\hline
\end{tabular}

TABLE V: COEFFICIENTS FOR INTEGRATED INDEPENDENT AND DEPENDENT VARIABLES

a. Dependent Variable: Leadership Performance. 
Before we interpret the coefficients, we ask ourselves if the coefficients are significant from zero and the answer is yes, the $p$-value for the overall model is .000 , less than .05 which means that the model is statistically significant. Therefore, based on the study, one may conclude that, taken together, all the independent variables have a significant positive effect on the change in the dependent variable, leadership performance of listed companies, at a $95 \%$ level of confidence.

It should also be noted that the coefficients of all the independent variables are positive, an indication that they all have a positive contribution to the leadership performance of listed companies in Kenya. The negative y-intercept means that in the absence of all the independent variables (i.e., when $\mathrm{X}_{\mathrm{i}}$ is zero), the dependent variable is negative (-4.802).

\section{REFERENCES}

Abdullah, M., Yasser, Q. R. and Rahman, A. (2013). A Discussion of the suitability of only one vs more than one theory for depicting corporate governance. Modern Economy, 4(1).

Agyemang, O.S. \& Aboagye, E. (2013) Ownership and control in corporate organisations in developing countries: evidence from a transition economy. European Journal of Business and Management ISSN 22221905, ISSN 2222-2839, 5(20).

Ajinkya, B.B., Atiase, R.K., Dontoh, A.K. \& Gift, M.J. (2011). The fundamental determinants of trading volume reaction to financial information: evidence and implications for empirical capital market research. Journal of Financial Research, 34(1), 61-101, Spring 2011.

Albrecht, W., Albrecht C. C., Albrecht, C. O. (2013). Fraud and Corporate Executives: Agency, Stewardship and Broken Trust. 5th edn,

Alchian, A. A. and Demsetz, H. (1972). Production, Information Costs and Economic Organization. American Economic Review, 62, 772-795.

Berle, A.A. and Means, G.C. (2011). The Modern Corporation and Private Property. New York, NY: Macmillan.

Block, P., \& Piersanti, S., (2013). Stewardship: Choosing Service Over SelfInterest. $2^{\text {nd }}$ Edn, Beret-Koehler Publishers, 235 Montgomery Street Suite 650, San Francisco, California 94104-2916.

Bossidy, L., \& Charan, R. (2012). Execution - The discipline of getting things done. New York: Crown Publishing Group.

Chenhall, R. H. \& Langfield-Smith, K. (2011). Management Accounting: Retrospect and Prospect. Accounting Review, 86 (6), 2186-2188.

Chung, K.H., Kim, J.S., Park, K. and Sung, T., (2013). Corporate governance, legal system, and stock market liquidity: evidence around the world. Asia-Pacific Journal of Financial Studies, 41 (6), 686-703.

Clarke, T. and Branson, D., (2012). The SAGE Handbook of Corporate Governance. Sage Publications Ltd, 1 Olivers Yard, 55 City Rd, London EC1Y 1SP.

Covey, S. R. (2011). 8th Habit from Effectiveness to Greatness. Simon \& Schuster UK Ltd, 1st Floor, 222 Gray's Inn Road London WC1X 8HB, pgs 74,98

Coward, R. (2010). Educational governance in the NHS: a literature review. International Journal of Health Care Quality Assurance, 23(8), 708717.

Curral, S.C., Frauenheim, E., Perry, S.J. and Hunter, E.M., (2014). Organized Innovation: A Blueprint for Renewing America's Prosperity. Oxford, UK: Oxford University Press.

Cyert, R. M. and March, J. G. (1963). A Behavior Theory of the Firm. New Jersey-USA, Prentice Hall.

Darley, W.K., Luethge, D.J. \& Blankson, C. (2013). Culture and International Marketing: A Sub-Saharan African Context. Journal of Global Marketing, 26, 188-202. DOI: 10.1080/08911762.

Donaldson, T. \& Preston, L.E. (1995). The stakeholder theory of the corporation: concepts, evidence and implications. Academy of Management Review, 20(1), 65-91.

Dutta, S., \& Fan, Q. (2014). Equilibrium earnings management and managerial compensation in a multiperiod agency setting. Review of Accounting Studies, 19(3), 1047-1077. DOI:10.1007/s11142-0149279-6.

Fisher, M., Strickland, B. \& Knobe, J. (2012). Moral structure falls out of general event structure. Psychological Inquiry, 23(2), 198-205.

Freeman, R. E. (2010). Strategic Management: A Stakeholder Approach. Cambridge University Press, New York.
Gossel, S.J. and Biekpe, N. (2014). The Relationship between Trade and Economic Growth in South Africa Before and After Liberalisation: A Causality Analysis. The Journal of International Trade \& Economic Development: An International and Comparative Review, 23(6) 815836.

Hannagan T; 2008: Leadership concepts \& Practices; Fifth Edition; Published by Pearson Education Limited.

Hillman, A. J., Canella, A. A. and Paetzold, R. L. (2000). The resource dependency role of corporate directors: strategic adaptation of board composition in response to environmental change. Journal of Management Studies, 37(2), 235-255.

Hoskisson, R., Johnson, R., Tihany, L. \& White, R. E. (2005). Diversified Business Groups and Corporate Refocusing in Emerging Economies. Journal of Management and Governance, 31, 941-965.

Hudson, A., (2013). Securities law. Sweet and Maxwell, 2edn. London.

Ibrahim Index of African Governance (2007) Retrieved from http://mo.ibrahim.foundation/iiag, on 02 Oct 2015

Iraya, C., Mwangi, M., Muchoki, G. W. (2015). The effect of corporate governance practices on earnings management of companies listed at the Nairobi securities exchange. European Scientific Journal January 2015 Edition Vol. 11; European Scientific Institute, Ponta Delgada Azores, Portugal

Jensen, M.C. \& Meckling, W.H. (1976). Theory of the Firm: Managerial behaviour, agency costs and ownership structure. Journal of Financial Economics, 4, 305-360.

Johnson, J. L., Daily, C. M. and Ellstrand, A. E. (1996). Boards of Directors: A Review of Research Agenda. Journal of Management, 22(3), 409438.

Kaufmann, D., Kraay, A., and Mastruzzi, M. (2012). The worldwide governance indicators: methodology and analytical issues. Hague Journal on the Rule of Law, 3 (02), 220-246.

Keraro, V. N. (2014). Role of Governance in the Strategic Management of Counties in Kenya. PhD Thesis. JKUAT, Nairobi

La-Porta, R., Lopez-de-Silanes, F., Shleifer, A., \& Vishny, R. (2002). Investor Protection and Corporate Valuation. Journal of Finance, 57 1147-1170.

Lashgari, M. (2014). Corporate Governance: Theory and Practice. The Journal of American Academy of Business, Cambridge University of Hartford, West Hartford, CT

Lev, B., Demerjian, P., and McVay, S. (2012). Intangibles: Quantifying Managerial Ability: A New Measure and Validity Tests Washington, Management Science, 58(7), 1229-1248, ISSN 0025 1909.

Levenson, A. R., \& Stede, W. A. (2011). Management accounting research in the wake of the crisis: some reflections. European Accounting Review, 20 (4), 605-623.

Liston, D. P; Chong, G; Bayram, S. G; (2014). The Impact of Political Variables on Stock Returns and Investor Sentiment, Asia Pacific Journal of Medical Toxicology; April 2014, 26(1), 176.

Liu, L. \& Subramaniam, N., (2013). Government ownership, audit firm size and audit pricing: Evidence from China. Journal of Accounting and Public Policy, 32 (2), 161-175.

Mackenzie, C. (2014). Boards, incentives and corporate social responsibility: the case for a change of emphasis. Corporate Governance: An International Review, 15(5), 935-43.

Madiavale, C. (2011). The Relationship Between Corporate Governance and Financial Performance of Previously Government Owned Companies Quoted on the Nairobi Stock Exchange. MBA Project, University of Nairobi.

Malina, M. A. \& Euske, K.J. (2013). Transfer of performance measurement innovations across economic sectors. Advances in Management Accounting, 22: 25-42.

Mallin, C.A., (2015). Corporate Governance. 5th edn. New York: NY, Oxford University press.

Marshall, C., \& Rossman, G.B. (2010). Designing qualitative research. New York: Sage Pulications.

Maurborgne, R, \& Kim W. C. (2015). Business strategy: Red ocean traps, Harvard Business Review.

McConvill, J. (2012). Laying the Foundations for Fund Fortune: Developments and Opportunities within EU Offshore Financial Centres in an AIFM Directive Age. Macquarie Journal of Business Law, 9. pp. 145-157. ISSN 1449-0269

Mensah, S. (2012). Corporate governance in Ghana: issues and challenges. Paper presented at African Capital Markets Conference, December 2012.

Merchant, K.A., Stede, W.A., Lin, T.W. and Yu, Z., (2011). Performance measurement and incentive compensation: an empirical analysis and comparison of Chinese and Western firms' practices. European Accounting Review, 20 (4), 639-667. 
Miring'u, A. N. \& Muoria, E.T. (2011). An analysis of the effect of Corporate Governance on Performance of Commercial State Corporations in Kenya. International Journal of Business and Public Management, (ISSN: 2223-6244), 1(1),36-41.

Mishra, S. \& Mohanty, P. (2014). Corporate governance as a value driver for firm performance: evidence from India. Corporate Governance: The international journal of business in society, 14(2), 265-280 http://dx.doi.org/10.1108/CG-12-2012-0089.

Mitchell, R. K., VanBuren, H. J., Greenwood M., and Freeman, R.E. (2015). Stakeholders inclusion and accounting for stakeholders. Journal of Management Studies, 52(7), 851-877. http://onlinelibrary.wiley.com/doi/10.111/joms.12151.

Muka, S. (2012). The relationship between corporate governance and ownership structures of firms listed at the Nairobi Stock Exchange. MBA Thesis, University of Nairobi.

Mulili, B. M. (2011). Towards the best corporate governance practices model for public universities in developing countries: the case of Kenya. DBA thesis, Southern Cross University, Lismore, NSW.

Mwanje, M. O., Guyo, W. \& Muturi, W. (2016). The Management Perception on the Effect of Managerial Skills towards Challenges of Strategy Implementation in Selected Sugar Companies in Kenya International Journal of Innovative Social Sciences \& Humanities Research, 4(2), 1-19, Apr-Jun. SEAHI PUBLICATIONS.

Nafukho, F. M., \& Muyia, M.A. H. (2014). Entrepreneurial leadership and transformation of universities in Africa. Governance and transformation of Universities in Africa. Charlotte, NC: Information Age Publishing.

Njanja W, L., Ogutu M., Pellisier R., (2012). The Effects of the External Environment on Internal Management Strategies within Micro, Small and Medium Enterprises; Kenyan Case. International Journal of Business and Management, 7(3).

NSE, (2015). Nairobi Stock Exchange, Retrieved from http//: www.nse.co.ke/ on 02 Oct 2015

Okpara, J.O. (2011). Corporate governance in a developing economy: barriers, issues, and implications for firms. Corporate Governance, 11(2), 184-199.

Opiyo, E. (2013), Effects of corporate governance on insider trading: A case of listed companies on Nairobi securities exchange. Prime Journal of Business Administration and Management(BAM). ISSN: 2251-1261. $3(10), 1202-1224$, October $18^{\text {th }}, 2013$.

Pallant, J., (2010). SPSS Survival Manual: A step by step guide to date analysis using SPSS. 4th edn. Maidenhead: Open University Press/McGraw-Hill.

Porter, M. (1992). Competitive strategy: Creating and sustaining superior performance. New York, NY: Free Press.

Reed, D. (2002). Corporate governance in developing countries. Journal of Business Ethics, 37(3), 223- 247.

Royston, P. (1982). An extension of Shapiro and Wilk's, W Test for Normality to Large Samples. Applied Statistics. 31:2.

Schouten, E., Wade, M. \& Wit, M., (2006). Hardwiring and softwiring corporate responsibility: a vital combination. Corporate Governance, $6(4), 491-505$

Solomon, J. (2013), Corporate Governance and Accountability, $4^{\text {th }}$ edn Wiley, Chichester.

Starik, M. \& Rands, G. (1995). Weaving an integrated web: multilevel and multisystem perspectives in ecological sustainability organizations. Academy of Management Review, 20(4), 908-35.

Subramaniam, N., Stewart, J. and Shulman, A. (2013). Understanding corporate governance in the Australian public sector: A social capita approach. Accounting, Auditing \& Accountability Journal, 26 (6), 946977.

Tabachnick, B.G., \& Fidell, L.S. (2007). Using multivariate statistics. Boston: Pearson/Allyn \& Bacon.

Turnbull, S. (2002). A New Way to Govern Organizations and Society After Enron. New Economics Foundation, London.

Watkins, S. (2003). Former Enron vice president Sherron Watkins on the Enron collapse. Academy of Management Executive, 17(4), 119-25.

Wellage, N. H., 2012. Corporate Governance and Financial Performance of Sri Lankan Listed Companies 2006-2010. PhD thesis, The University of Waikato, NewZealand.

Williamson, O. (1996). The Mechanisms of Governance. Oxford University Press, Oxford

Yang, J. (2012). Does Adopting High-Standard Corporate Governance Increase Firm Value? An Empirical Analysis of Canadian Companies. International Business \& Economics Research Journal, The Clute Institute, 10(9).

Zandstra, G. (2012). Enron, board governance and moral failings. Corporate Governance, 2(2), 16-19.

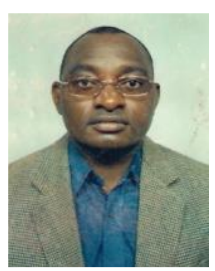

R. M. Isaac is a Dean and senior Lecturer of Business Management at the School of Business, The East African University, Kenya. Dr. Isaac received his Ph.D. from Jomo Kenyatta University of Agriculture and Technology in 2018, Kenya, and MBA in Business Administration from Kenyatta University in 2012, Kenya.

Dr. Isaac has worked in government and private sectors in MANAGEMENT level positions. He has published several articles including:

Steering Business in Kenya through Difficult Environment, European Journal of Business and Management, ISSN 2222-1905 (Paper) ISSN 2222-2839 (Online).13(24), 70-75.2021.

Dr. Isaac is a member of Engineers Board of Kenya, Institution of Workplace and Facilities Management, UK, Kenya Institute of Management and Institution of Engineers of Kenya. He is a Project Management, Leadership and Governance, and Facilities Management consultant. 